\title{
Problemas de alimentação em crianças com doença do refluxo gastroesofágico $* * *$
}

\author{
Feeding disorders in children with gastro-esophageal reflux disease
}

\author{
Larissa Vieira Drent* \\ Elizete Aparecida Lomazi da Costa Pinto**
}

\begin{abstract}
*Fonoaudióloga. Mestre em Saúde da Criança e do Adolescente pela Faculdade de Ciências Médicas da Universidade Estadual de Campinas. Endereço para correspondência: Rua Antônio Rodrigues Moreira Neto, 311 - Apto. H11 - Campinas - SP - CEP 13060-073 (lvdrent@yahoo.com.br).

**Médica Pediatra. Professora Doutora em Saúde da Criança e do Adolescente pela Faculdade de Ciências Médicas da Universidade de Campinas. Professora Assistente Doutora do Departamento de Pediatria da Faculdade de Ciências Médicas da Universidade de Campinas.

***Pesquisa Realizada no Centro de Investigação em Pediatria da Faculdade de Ciências Médicas da Universidade de Campinas.
\end{abstract}

Artigo de Pesquisa

Artigo Submetido a Avaliação por Pares

Conflito de Interesse: não

Recebido em 14.02.2006.

Revisado em 12.09.2006; 06.02.2007.

Aceito para Publicação em 06.02.2007.

\begin{abstract}
Background: feeding/eating disorders are frequent in pediatric patients and, in some cases, can be associated to an upper digestive motility disorder. Gastro-esophageal reflux is, nowadays, considered a risk factor for the development of feeding/eating disorders. Aim: to verify the occurrence of feeding/eating disorders in patients with Gastro-Esophageal Reflux Disease (GERD) determined by the 24-H esophageal pH monitoring evaluation. Method: an analytical observational cross-sectional study of the stomathognatic system and feeding/eating behavior in healthy children and in children with GERD. Results: 25 children (ages 45,68 $\pm 34,22$ months; mean \pm SD) with the diagnosis of GERD determined by the 24-H esophageal $\mathrm{pH}$ monitoring evaluation and 40 children (ages 60,65 \pm 36,07 months; mean \pm SD) randomized from their school group. The criteria for the $\mathrm{pH}$ monitoring were: vomiting, regurgitation, wheezing and recurrent pneumonia. There was no significant difference in age mean between groups. Children with GERD presented an significantly higher frequency $(\mathrm{p}<0.05)$ of feeding/eating problems $(\mathrm{F} / \mathrm{EP})$ and of oral motor-sensory disturbances (sucking, chewing and swallowing). Behavioral F/EP was present in $44 \%$ of the cases and oral motor-sensory F/EP in $80 \%$. About $64 \%$ of the children had a history of feeding/eating complaints, $36 \%$ presented an extended feeding/eating time, $68 \%$ presented problems in the development of the oral feeding patterns and $60 \%$ presented alterations in the nasal breathing pattern. Conclusion: children with GERD presented a higher prevalence of behavioral and stomathognatic feeding/eating problems when compared to healthy children.
\end{abstract}

Key Words: Gastro-Esophageal Reflux; Feeding Behavior; Speech and Language Therapist.

\section{Resumo}

Tema: a queixa de problema alimentar é freqüente na faixa pediátrica, podendo apresentar associação com problemas de motilidade digestiva superior. A doença do refluxo gastro-esofágico (DRGE) é considerada hoje em dia um dos fatores de risco para o desenvolvimento de problemas de alimentação. Objetivo: verificar a ocorrência de problemas de alimentação em pacientes com DRGE definida pelo exame de pHmetria esofágica de 24 horas. Método: estudo analítico observacional transversal da das funções estomatognáticas e do comportamento alimentar em crianças com quadro clínico de DRGE e crianças saudáveis. Resultados: foram avaliadas 25 crianças $(45,68 \pm 34,22$ meses; média e desvio padrão) com diagnóstico de DRGE realizado por meio da pHmetria e 40 crianças $(60,65 \pm 36,07$ meses) sorteadas do grupo escolar. Os critérios para a solicitação do exame de pHmetria foram a presença de manifestações como vômito, regurgitação, chiado e pneumonias de repetição. Não houve diferença significativa entre as médias de idade. Houve ocorrência estatisticamente significante ( $\mathrm{p}<0,05)$ de problemas de alimentação (PA) e distúrbio das funções orais (distúrbios de sucção, mastigação e deglutição) no grupo de crianças com DRGE. PA de ordem comportamental esteve presente em $44 \%$ dos casos e PA de ordem estomatognática em $80 \%$. Cerca de $64 \%$ das crianças apresentaram histórico de queixa de problema alimentar, $36 \%$ aumento do tempo de alimentação, $68 \%$ problemas no desenvolvimento dos padrões orais de alimentação e $60 \%$ alteração do modo respiratório nasal. Conclusão: Crianças com DRGE apresentam maior prevalência de problemas alimentares de ordem comportamental e estomatognática quando comparadas a crianças saudáveis.

Palavras-Chave: Refluxo Gastroesofágico; Comportamento Alimentar; Sistema Estomatognático.

Referenciar este material como:

1 DRENT, L. V.; PINTO, E. A. L. C. Feeding disorders in children with gastro-esophageal reflux disease (original title: Problemas de alimentação em crianças com $\sum 3$ doença do refluxo gastroesofágico). Pró-Fono Revista de Atualização Científica, Barueri (SP), v. 19, n. 1, p. 59-66, jan.-abr. 2007. 


\section{Introduction}

Feeding problems are frequently seen in pediatric clinics and usually some difficulty is faced when attempting to characterize their etiology. Even when they do not cause nutritional repercussion or growth deficits, feeding disorders may interfere with the child and family's quality of life, by getting in the way of normal feeding patterns. From the speech-language therapist point of view, it can be said that a normal feeding pattern is not satisfactory when adequate child diet does not favor the development of oral-motor functions, or when there is a risk of choking.

Feeding disorders frequency vary from 25 - 35\% in healthy children, and from $40-70 \%$ in preterm neonates or in children with chronic and consumptive diseases, and finally, may affect up to $80 \%$ of neurologically impaired children. The diagnosis of feeding and eating disorders frequently occurs in children ages 2 to 7 (Douglas \& Byron, 1996; Burklow et al., 1998; Goldani, 1999; Manikan \& Perlman, 2000).

Feeding problems do not indicate a specific clinical entity with an isolated organic or nonorganic etiology. In most cases, they result from the interaction between organic, socio-cultural and behavioral factors (Gillespie \& Acterberg, 1989; Dellert et al., 1993; Douglas \& Byron, 1996; Burklow et al., 1998; Meira, 1998; Manikan \& Perlman, 2000; Suss-Burghart, 2000; Tuchman, 2000; Cattoni et al., 2001; Ramsay et al., 2002; Rudolph \& Link, 2002; Madeira \& Aquino, 2003; Rommel, 2003; Staiano, 2003; Strudwick, 2003; Cooper et al., 2004).

Children referred for evaluation by a speechlanguage therapist due to feeding problems usually present uniform clinical manifestations, even when facing a range of determinant factors (Goldani 1999; Manikan \& Perlman, 2000). Data on clinical symptoms shows that $52 \%$ of pre-school children do not present consistent hunger during feeding, $42 \%$ finish a meal quickly, $35 \%$ may be considered "picky-eaters", and about 33\% display evident feeding selectivity. Reports from parents and caretakers show that $78 \%$ of feeding problems are related to insufficient ingestion, 30\% due to food selectivity, and $50 \%$ due to difficulties in accepting a different food texture. Other symptoms such as eating slowly, selective or regular vomiting, holding food in mouth and family anguish during the child's feeding, are also reported. (Douglas \& Byron, 1996; Goldani, 1999).

Clinical manifestations of gastroesophageal reflux disease (GERD) in children includes vomiting, regurgitation, poor weight gain, functional dysphagia, dysphonia, acidic or bitter taste in the mouth, nausea, postprandial discomfort, abdominal and/or retrosternal pain, irritability and breathing problems (Rudolph et al., 2001). Additionally, authors report that esophagitis is one of the main factors associated to feeding refusal, irritability during meals, poor ingestion, and the rejection of certain food textures and consistencies (Nelson et al., 1998; Manikan \& Perlman, 2000).

Goldani (1999) did not identify motor disorders when studying swallowing and esophageal peristalsis in children with GERD. However, some studies suggest that peptic esophagitis may result in the above-mentioned feeding symptoms (Nelson, 1998; Manikan \& Perlman, 2000).

Considering that there is limited data available in the literature, that the symptoms related to feeding problems and GERD may be similar and that these entities may in fact be related, this study was conducted with the objective of systematically evaluating feeding functions in children with GERD.

\section{Method}

A Local Ethics Committee approved this study and all the parents/caretakers involved in the research signed a legal consent form.

During the period of 16 months, 77 patients with clinical diagnosis of GERD disease were consecutively referred to a Tertiary School Hospital. Pediatric gastroenterologists evaluated each patient and $24 \mathrm{H}$ esophageal $\mathrm{pH}$ monitoring was requested according to ESPGAN protocol recommendations (RERKSUPPAPHOL \& BARNES, 2002). In total, 56 children were underwent of $\mathrm{pH}$ monitoring. Patients with neurological disorders, genetic syndromes, chronic pulmonary diseases or heart diseases were excluded. A speech-language therapist evaluated 36 children focusing on the stomatognathic system. Twenty-five children diagnosed with GERD (45.68 \pm 34.22 months; mean $\pm \mathrm{SD}$ ), according $24 \mathrm{H}$ esophageal $\mathrm{pH}$ monitoring, composed a GERD group.

The healthy children, $\mathrm{N}=40,(60.65 \pm 36.07$ months) were selected from a pre-school located in an area with demographic conditions similar to the patients demography. A teacher at the school selected the control children at random, firstly excluding children whit previously known disease. In order to accurately match for sex and age, the control children were selected by the teacher immediately following the inclusion of the GERDpatient in the study. The control children underwent 
the same clinical procedures applied to the GERD group and the resulting data was compared.

The prolonged esophageal $\mathrm{pH}$ monitoring procedure was performed using Synetics Medical pediatric catheters, with an electrode located at T7/ T8 level (confirmed by thorax radiography). The $\mathrm{pH}$ reading was performed using the system Digitrapper MKIII, and recorders were analyzed using Gastrosoft Inc software. Monitoring was considered abnormal when the reflux index (RI) was over $4 \%$ in children over 12 months old and RI over $10 \%$ in children under 12 months old. During monitoring, habitual diet was administered with a minimal interval of 3 hours, and children over 12 months old were not fed at night. Prokinetic, xanthin and anti-acid drugs were also suspended at least 48 hours before the procedure.

The speech-language therapist evaluation aimed to investigate stomatognathic disorders possibly interfering with feeding. The clinical examination was performed during the hospital admission for $\mathrm{pH}$ monitoring and was completed before inserting nasal catheter and according to the following stages:

Stage 1

A structured questionnaire (anamnesis) was used to gather specific descriptions of the child's eating behavior. Additional clinical data was obtained from clinical charts. The following variables were considered for feeding behavior diagnosis: "Complaints of feeding problems", "Lengthy feeding time", "Evident food selectivity", and "Abnormalities in the development of eating functions" according to Table 1, and based on studies of Marchesan (1998a) and Morris \& Klein (2000).

\section{Stage 2}

Evaluation of stomatognathic structures such as lips, tongue, soft and hard palates, lip and lingual frenum, teeth, gums, cheeks and tonsils, that are involved in sucking, chewing and swallowing functions.
Stage 3

Evaluation of stomatognathic functions. This procedure was done to identify sucking, chewing and swallowing disorders. Each child was offered a glass of water (liquid consistency), Maizena ${ }^{\circledR}$ cookies (solid) and yogurt on a spoon (paste). The three consistencies were offered in order to observe stomatognathic system performance at different motor demand levels. Evaluation of children from 3 to 12 months old was done by observing breastfeeding or bottle-feeding in accordance with the child's regular routine.

The final diagnosis of feeding problems was established taking into consideration the following clinical possibilities: Presence of feeding problems, Presence of behavioral feeding problems and Presence of stomatognathic feeding problems. The association between behavioral and stomatognathic feeding problems was proven to be a possible diagnosis.

The data set and statistical analysis were processed using the software SPSS for Windows version 7.0. Chi-square or Fisher tests were used in order to compare the categorical variables. AMannWhitney U test was used to compare age distribution in groups. The significance level adopted was $5 \%$.

\section{Results}

The following table shows frequency of symptoms that justified $\mathrm{pH}$ monitoring.

The mean age values of patients and controls were respectively $45.7 \pm 34.2$ months and $60.7 \pm$ 36.0 months. There were no significant age distribution differences in the groups.

Tables 2 and 3 show the frequency of complaints associated with feeding behavior and stomatognathic dysfunction.

The final diagnosis revealed that 23 children with GERD and 19 healthy children, within the control group, had feeding disorders. These numbers demonstrate the existence of significant differences between children with GERD and the healthy children in the control group. A significant difference was also observed when considering the Behavioral feeding problems and Stomatognathic disorder variables (Table 4). 
CHART 1: Development stages of feeding oral patterns, based on Marchesan (1998) and Morris (2000).

Age $\quad$ Type of food

Stage I Around 4 months $\quad$ Paste consistency: paste and fruits puree

Stage II Around 7 months $\quad$ Semi-solid consistency -: Cooked food, smashed with a fork

Stage III From 12 months on Solid consistency: Child is able to chew rice, beans, cookies, fruits and meats

TABLE 1. Symptoms that justified esophageal $\mathrm{pH}$ monitoring $(\mathrm{N}=25)$.

\begin{tabular}{lcc}
\hline \multicolumn{1}{c}{ Variables } & Frequency & $\%{ }^{*}$ \\
\hline & 10 & 32.3 \\
Digestive Manifestations & & 25.8 \\
$\begin{array}{l}\text { Breathing manifestations } \\
\text { (Recurrent pneumonias and wheezing) }\end{array}$ & 8 \\
$\begin{array}{l}\text { Combined manifestations } \\
\text { (Digestive and breathing) }\end{array}$ & 13 \\
\hline
\end{tabular}

* some children had more than one symptom.

TABLE 2. Distribution of complaints associated with feeding behavior disorder in groups: GERD and Healthy.

\begin{tabular}{|c|c|c|c|}
\hline & GERD $(\mathrm{N}=25)$ & HEALTHY $(\mathrm{N}=40)$ & $\mathrm{p}$ \\
\hline əding problem complaint $*$ & $16(64 \%)$ & $7(17,6 \%)$ & 0.000 \\
\hline rease meal times $*$ & $9(36 \%)$ & $3(7,5 \%)$ & 0.007 \\
\hline ident food selectivity $*$ & $5(20 \%)$ & $4(10 \%)$ & NS \\
\hline sblems of oral feeding patterns $* *$ & $17(68 \%)$ & $4(10 \%)$ & 0.000 \\
\hline \multicolumn{4}{|c|}{$*$ Fisher exact test; $* *$ Chi-Square test; NS not significant } \\
\hline & GERD $(\mathrm{N}=25)$ & HEALTHY (N=40) & $\mathrm{p}$ \\
\hline \multicolumn{4}{|l|}{ OMATOGNÁTHIC DIAGNÓSIS } \\
\hline matognathic structures disorders $*$ & $11(44 \%)$ & $10(25 \%)$ & NS \\
\hline sal breathing pattern disorder $*$ & $15(60 \%)$ & $10(25 \%)$ & 0.008 \\
\hline cking disorder $* *$ & $11(44 \%)$ & $5(12,5 \%)$ & 0.005 \\
\hline ewing disorder $* *$ & $15(60 \%)$ & $14(35 \%)$ & NS \\
\hline 'allowing disorder * & $15(60 \%)$ & $9(25 \%)$ & 0.004 \\
\hline k of choking $*$ & $4(16 \%)$ & 0 & 0.019 \\
\hline
\end{tabular}

* Fisher exact test; ** Chi-Square test; NS not significant. 
TABLE 4: Final speech-language diagnosis in groups: GERD and Healthy

\begin{tabular}{lccc}
\hline & $\begin{array}{c}\text { GERD } \\
(\mathrm{N}=25)\end{array}$ & $\begin{array}{c}\text { HEALTHY } \\
(\mathrm{N}=40)\end{array}$ & $\mathrm{p}$ \\
\hline AGNÓSIS & & & \\
eding problem * & $23(92 \%)$ & $19(47.5 \%)$ & 0.000 \\
:havioral feeding problem * & $11(44 \%)$ & $4(10 \%)$ & 0.002 \\
omatognathic feeding problem * & $20(80 \%)$ & $16(40 \%)$ & 0.002 \\
\hline * Fisher exact test. & & &
\end{tabular}

* Fisher exact test.

\section{Discussion}

Children with GERD, diagnosed by $\mathrm{pH}$ monitoring, presented a significantly higher frequency of feeding problems and stomatognathic function disorders than their healthy counterparts. Sucking, swallowing and chewing disorders were found to be more frequent among children with GERD.

According to Strudwick (2003), children with GERD may develop oral hypersensitivity, which makes the acceptance of food with different consistencies and textures more difficult. Meira (1998) reports that recurrent regurgitation, pain and discomfort after ingestion may trigger oral hypersensitivity, as well as food restriction and refusal. According to these authors, patients with esophagitis display physical pain during feeding which causes a variety of feeding problems.

Considering the current patients examined in this study, sucking disorders occurred more frequently in children with GERD and many times were manifested by difficulty to closing the lips, exaggerated efforts when sucking and regurgitation. According to Meira (1998) and Souza $\&$ Bitar's (2003) studies, when these symptoms are recurring, they may create an imbalance in the tension of the posterior mouth muscles and cervical area, which impairs the performance of the stomatognathic system. The present research study design could not determine whether feeding problems were caused by gastro-esophageal reflux, or if their presence motivated a certain suspicion that GERD may be present.

There was no difference in the frequency of chewing disorders between children with reflux disease and healthy controls. The mean age in GERD children coincides with an immature chewing stage, commonly seen after the loss of baby teeth
(Motta \& Costa, 2002). It is possible that this stage acts as a main factor for the occurrence of chewing disorders in the control group, although their presence was not strong enough to generate significant feeding problems. Among patients with GERD, it is possible that digestive symptoms, resulting from the complications that accompany reflux, may have caused discomfort and displeasure during feeding time and promoted functional disorders. Introducing changes in diet and using liquid consistencies are common food administration alternatives used to help facilitate food acceptance. However, these replacements do not favor the maturation of oral feeding and may result in chewing immaturity. According to Douglas \& Byron (1996), the postprandial discomfort associated with reflux may be responsible for the reduction of food ingestion, lack of interest in the meal and the behavior of holding food in the mouth, later spitting it out without having chewed it.

Swallowing function disorders were significantly more frequent in the GERD group. In about $60 \%$ of children dysfunction involved an oral phase disorder without the risk of choking. This result indicates that disorders are most likely present in other mechanisms besides those involved with oral dynamics. In other words, an esophageal proximal motility disorder may be able to generate swallowing problems. According to Junqueira \& Costa (2001), it is possible to find a significant correlation between chewing disorders and the oral phase of swallowing disorders in patients with GERD and/or neuropathy. Somani et al. (2004) observed the presence of esophageal motor disorders in patients with GERD. Ferriolli et al. (1998) identified esophageal aperistalsis in patients with reflux esophagitis. In contrast, 
Goldani's (1999) study of neurologically impaired children with GERD and feeding problems, did not identify any disturbances in the esophageal motor function.

The occurrence of a nasal breathing pattern disorder in $60 \%$ of children with reflux was statistically higher than findings in healthy children. Oral breathing may impede the performance of stomatognathic functions for feeding (Marchesan, 1998b; Junqueira et al, 2002) and some studies have considered that GERD when diagnosed by esophageal $\mathrm{pH}$ monitoring, may be the cause of otorhinolaryngological conditions (Ahmad \& Bath, 2004; Richter, 2004; Yuan \& Winter, 2004). However, according to Rabinowitz et al. (2003), identifying the relationship between reflux and otorhinolaryngological manifestations is a difficult approach, once standardized methods for evaluation proximal esophageal third contents in patients with such symptoms are not routinely used.

Oral breathing in children with GERD has been associated with nasal obstruction, which occurs when mucous in the upper respiratory tract is exposed to stomach acids. In children from the control group the presence of an altered breathing pattern is considered to be a possible behavior deviation acquired during an acute viral disease that temporarily blocks the nasal passages. In these cases of acute viral disease in otherwise healthy children, an altered breathing pattern frequently becomes a habit and is not associated with anatomic nasal obstruction and does not interfere with feeding. Even after recovering from viral upper respiratory diseases and obtaining full rehabilitation of the nasal passages, it has been demonstrated that nasal breathing may sometimes be re-learned by children (Marchesan, 1998b; Moralles, 2002).

Unfavorable feeding conditions in children with GERD, which are associated with the significant occurrence of stomatognathic function disorders, may contribute to the frequency of feeding disorder complaints, while also providing a possible explanation for the significant increase in meal times. It was shown that GERD does not have a significant association with the presence of rejection and selectivity behavior, but it is in fact related to the developmental delay of oral feeding acquisition. Throughout the research, it was observed that a lack of interest in food was not due to specific food characteristics such as flavor, smell, temperature, consistency and texture, but rather, to the feeding context in general. It is possible that children had adopted food exclusion, rejection and other selective behaviors to their daily diet routines. According to Douglas \& Byron (1996), Goldani (1999), Manikan \& Perlman (2000), Rudolph \& Link (2002) and Strudwick (2003), parents of children with feeding problems tend to restrict their children's food options in an effort to avoid difficulties generated by food (i.e. emotional disorganization in the family environment during meal time and difficulty finishing the meal within a reasonable time).

Pediatric teams usually consider food restriction to be irrelevant as long as it does not interfere with weight gain or result in stunted growth (Dellert et al., 1993). Nevertheless, not accepting/experiencing different food consistencies and textures, may promote the maintenance of immature oral functions by depriving children of certain sensory-motor experiences that are necessary in order to acquire new sucking, chewing and swallowing patterns. The presence of stomatognathic problem may limit ingestion opportunities, which suggests that the intervention of speech-language therapists should be performed in conjunction with other treatment procedures that aim to improve oral feeding functions and oral-motor development of children with GERD.

\section{Conclusion}

Speech-language therapists evaluation and investigation of stomatognathic system and feeding behavior, suggests that children with GERD present a higher prevalence of behavioral and stomatognathic feeding problems when compared with healthy children. Their findings reveal that this association between GERD and oral-motor function disorders may generate feeding problem complaints, an increase in feeding time and delayed oral feeding functions acquisitions. 


\section{References}

AHMAD, I.; BATH, A. J. G. Acid reflux management: ENT perspective. J. Laryngol. Otol., Birmingham (UK), v. 118, p. 25-30, jan. 2004 .

BURKLOW, K. A.; PHELPS, A. N.; SCHULTZ, J.; MCCONNELL, K.; RUDOLPH, C. Classifying complex pediatric feeding disorders. J. Pediatr. Gastroenterol. Nutr., Philadelphia, v. 27, n. 2, p. 143-147, ago. 1998.

CATTONI, D. M.; ANDRADE, D. R. F.; ZACKIEWICZ, D. M.; NEIVA, F. C. B. Levantamento da consistência do alimento recebido no primeiro ano de vida. $R$. Soc. Bras. Fonoaudiol., São Paulo, v. 6, n. 1, p. 59-64, jun. 2001.

COOPER, P. J.; WHELAN, E.; WOOLGAR, M.; MORRELL, J.; MURRAY, L. Association between childhood feeding problems and maternal eating disorder: role of the family environment. Br. J. Psychiatry, Londres, v. 184 , p. 210-215, mar. 2004.

DELLERT, S. F.; HYAMS, S. J.; WILLIAM, R. T.; GEERTSMA, A. Feeding resistance and gastroesophageal reflux in infancy. J. Pediatr. Gastroenterol. Nutr., Philadelphia, v. 17, n. 1, p. 66-71, apr. 1993.

DOUGLAS, J. E.; BYRON, M. Interview data on severe behavioral eating difficulties in young children. Arch. Dis. Child, Nova York, v. 75, n. 4, p. 304-308, oct. 1996.

FERRIOLI, E.; OLIVEIRA, R. B.; MATSUDA, N. M.; BRAGA, F. J.; DANTAS, R. O. Aging, esophageal motility and gastroesophageals reflux. J. Am. Geriatr. Soc., Nova York, v. 46, n. 12, p. 1534-1537, dec. 1998.

GILLESPIE, A. H.; ACTERBERG, C. L. Comparison of family interaction patterns related to food and nutrition. J. Am. Diet. Assoc., Chicago, v. 89, n. 4, p. 509-512, abr. 1989.

GOLDANI, H. A. S. Motilidade do trato digestivo superior em crianças com problemas de alimentação e refluxo gastroesofágico. 1999. 99 f. Tese (Doutorado em puericultura e pediatria) - Faculdade de Medicina, Universidade de São Paulo. Ribeirão Preto.

JUNQUEIRA, P.; COSTA, M. M. B. Protocolo para avaliação videofluoroscópica da dinâmica da fase oral da deglutição de volume líquido. Pró-Fono R. Atual. Cient., Carapicuíba (SP), v. 13, n. 2, p. 165-168, set. 2001.

JUNQUEIRA, P. A. de S.; FRANCESCO, R. C. D.; TREZZA, P.; ZERATTI, F. E.; FRIZZARINI, R.; FARIA, M. E. J. de. Alterações funcionais do sistema estomatognático pré e pós-adenoamigdalectomia. Pró-Fono R. Atual. Cient., Carapicuíba (SP), v. 4, n. 1, p. 17-22, jan.-abr. 2002.

MADEIRA, I. R.; AQUINO, L. A. Problemas de abordagem difícil: "não come" e "não dorme". J. Pediatr., Rio de Janeiro, v. 79, p. S43-S54, may 2003. supl. 1.

MANIKAN, R.; PERLMAN, J. A. Pediatric feeding disorder. J. Clin. Gastroenterol., New York, v. 30, n. 1, p. 34-46, jan. 2000.

MARCHESAN, I. Q. Uma visão compreensiva das práticas fonoaudiológicas: a influência da alimentação no crescimento e desenvolvimento craniofacial e nas alterações miofuncionais. São Paulo: Pancast, 1998a. 238 p.

MARCHESAN, I. Q. Avaliação e terapia dos problemas da respiração. In: Fundamentos da fonoaudiologia: aspectos clínicos da motricidade oral. Rio de Janeiro: Guanabara Koogan, 1998b. p. 23-26.
MEIRA, R. R. S. Refluxo gastroesofágico: uma demanda na clínica pediátrica e a intervenção fonoaudiológica. In: MARCHESAN, I. Q.; ZORZI, J. L.; GOMES, I. C. D. (Org). Tópicos em fonoaudiologia. São Paulo: Lovise, 1998. p. 479-487.

MORALLES, R. C. O. Sucção, deglutição e mastigação fisiológicas. In: MORALLES, R. C. O. Terapia de regulação orofacial: conceito RMC. São Paulo: Memnon, 2002. p. 45-56.

MORRIS, S. E.; KLEIN, M. D. Pre-feeding skills: a comprehensive resource for mealtime development. 2. ed. Arizona (USA): Therapy Skill Builders, 2000. p. 31-41.

MOTTA, A. R.; COSTA, H. O. de O. A mastigação no período intertransicional da dentição mista. R. Dent. Press. Ortodon. Ortoped. Facial, Maringá (PR), v. 7, n. 5, p. 7786 , set.-out. 2002.

NELSON, S. P.; CHEN, E. H.; SYNIAR, G. M.; CHRISTOFFEL, K. K. One-year follow-up of symptoms of gastroesophageal reflux during infancy. Pediatrics, Springfield, v. 102, p. 1470-1481, dez. 1998.

RABINOWITZ, S. S.; PIECUCH, S.; JIBLY, R.; GOLDSMITH, A.; SCHWARZ, S. M. Optimizing the diagnosis of gastroesophageal reflux in children with otolaryngologic symptoms. Int. J. Pediatr. Otorhinolaryngol., Amsterdam, v. 67, n. 6, p. 621-626, jun. 2003.

RAMSAY, M.; GISEL, E. G.; McCUSKER, J.; BELLAVANCE, F.; PLATT, R. Infant sucking ability, nonorganic failure to thrive, maternal characteristics, and feeding practices: a prospective cohort study. Dev. Med. Child. Neurol., London, v. 44, n. 6, p. 405-414, jun. 2002.

RICHTER, J. E. Ear, nose and throat and respiratory manifestations of gastro-esophageal reflux disease: an increasing conundrum. Eur. J. Gastroenterol. Hepatol., London, v. 16, n. 9, p. 837-845, sep. 2004.

ROMMEL, N.; DE MEYER, A. M.; FEENSTRA, L; VEEREMAN-WAUTERS, G. The complexity of feeding problems in 700 infants and young children presenting to a tertiary care institution. J. Pediatr. Gastroenterol. Nutr., New York, v. 37, n. 1, p. 75-84, mar. 2003.

RUDOLPH, C. D.; MAZUR, L. J.; LIPTAK, G. S.; BAKER, R. D.; BOYLE, J. T.; COLLETTI, R. B.; GERSON, W. T.; WERLIN, S. L. Guidelines for evaluation and treatment of gastroesophageal reflux in infants and children: recommendations of the North American Society for Pediatric Gastroenterology and Nutrition. J. Pediatr. Gastroenterol. Nutr., New York, v. 32, p. S1-31, 2001. suppl. 2.

RUDOLPH, C. D.; LINK, D. T. Feeding disorder in infants and children. Pediatr. Clin. North Am., Philadelphia, v. 49, n. 1, p. 97-112, feb. 2002.

SOMANI, S. K.; GHOSHAL, U. C.; SARASWAT, V. A.; AGGARWAL, R.; MISRA, A.; KRISHNAMI, N.; NAIK, S. $\mathrm{R}$. Correlation of esophageal $\mathrm{pH}$ and motor abnormalities with endoscopic severity of reflux esophagitis. Dis. Esophagus, New York, v. 17, n. 1, p. 58-62, apr. 2004.

SOUZA, L. P. de.; BITAR, M. L. Alimentação de lactentes com refluxo gastresofágico (RGE). Pró-Fono R. Atual. Cient., Barueri (SP), v. 15, n. 2, p. 117-124, ago. 2003. 
STAIANO, A. Food refusal in toddlers with chronic diseases. J. Pediatr. Gastroenterol. Nutr., Philadelphia, v. 37, n. 3, p. 225-227, sep. 2003.

STRUDWICK, S. Gastro-oesophageal reflux and feeding: the speech and language therapist's perspective. Int. J. Pediatr. Otorhinolaryngol., Amsterdam, v. 67, n. 1, p. S101S102, dec. 2003. suppl. 1.
SUSS-BURGHART, H. Feeding disorders and failure to thrive in small and/or handicapped children. Z. Kinder Jugendpsychiat. Psychother., Alemanha, v. 28, n. 4, p. 285-296, nov. 2000.

TUCHMAN, D. N. Disorders of deglutition. In: WALKER, W. A.; DURIE, P. R.; HAMILTON, J. R.; WALKER-SMITH, J. A.; WATKINS, J. B. Pediatric Gastrintestinal Disorders. Ontário (Canadá): BC Decker Inc Hamilton, 2000. p. $277-$ 288.

YUAN, Q.; WINTER, H. S. Gastroesophageal reflux in children. In: FASS, R. GERD: dyspepsia. Filadélfia: Hanley \& Belfus Inc, 2004. p. 289-254 